\title{
An assessment system for rating scientific journals in the field of ergonomics and human factors
}

\author{
Jan Dul and Waldemar Karwowski
}

\begin{tabular}{|l|l|}
\hline \multicolumn{2}{|l|}{ ERIM REPORT SERIES RESEARCH IN MANAGEMENT } \\
\hline ERIM Report Series reference number & ERS-2003-048-LIS \\
\hline Publication & March 2003 \\
\hline Number of pages & 32 \\
\hline Email address corresponding author & j.dul@fbk.eur.nl \\
\hline Address & Erasmus Research Institute of Management (ERIM) \\
& Rotterdam School of Management / Faculteit Bedrijfskunde \\
& Rotterdam School of Economics / Faculteit Economische \\
& Wetenschappen \\
& Erasmus Universiteit Rotterdam \\
& P.O. Box 1738 \\
& 3000 DR Rotterdam, The Netherlands \\
& Phone: +31 10 408 1182 \\
& Fax: $\quad+31104089640$ \\
& Email: info@erim.eur.nl \\
& Internet: $\quad$ www.erim.eur.nl \\
\hline
\end{tabular}

Bibliographic data and classifications of all the ERIM reports are also available on the ERIM website: www.erim.eur.nl 


\title{
ERASMUS RESEARCH INSTITUTE OF MANAGEMENT
}

\author{
REPORT SERIES
}

RESEARCH IN MANAGEMENT

\begin{tabular}{|l|l|l|}
\hline BIBLIOGRAPHIC DATA AND CLASSIFICATIONS \\
\hline Abstract & $\begin{array}{l}\text { A method for selecting and rating scientific and professional journals representing the discipline } \\
\text { of ergonomics and human factors is proposed. The method is based upon the journal list, impact } \\
\text { factors and citations provided by the Institute of Scientific Information (ISI), and the journal list } \\
\text { published in the Ergonomics Abstracts. Three groups of journals were distinguished. The } \\
\text { 'ergonomics journals' focus exclusively on ergonomics or human factors. The 'related journals' } \\
\text { focus on other disciplines than ergonomics or human factors, but regularly publish } \\
\text { ergonomics/human factors papers. The 'basic journals' focus on other technical, medical or } \\
\text { social sciences than ergonomics, but are important for the development of ergonomics/human } \\
\text { factors. Journal quality was rated using a maximum of four categories: top quality (A-level), high } \\
\text { quality (B-level), good quality (C-level)) and professional (P-level). The above methods were } \\
\text { applied to develop journal ratings for the year 2003. A total of 24 'ergonomics journals', 58 }\end{array}$ \\
\hline 'related journals' and 142 'basic journals' were classified.
\end{tabular}




\title{
An assessment system for rating scientific journals in the field of ergonomics and human factors
}

\author{
Jan Dul1* and Waldemar Karwowski² \\ 1Department of Management of Technology and Innovation, Rotterdam School of \\ Management, Erasmus University Rotterdam, PO Box 1738, 3000 DR Rotterdam, \\ The Netherlands \\ ${ }^{2}$ Center for Industrial Ergonomics, University of Louisville, Lutz Hall, Room 445, \\ Warnock Street, Louisville, KY 40208, USA
}

Keywords: scientific journals, rating, impact factor

March 10, 2003

* Corresponding author:

Jan Dul,

Professor of Ergonomics Management,

Department of Management of Technology and Innovation,

Rotterdam School of Management/Faculteit Bedrijfskunde,

Erasmus University Rotterdam,

PO Box 1738, Room F2-59,

3000 DR Rotterdam,

The Netherlands.

Ph. + 31 (0) 10-4081719; Fax + 31 (0) 10-4089014

e-mail: j.dul@fbk.eur.nl 


\section{ABSTRACT}

A method for selecting and rating scientific and professional journals representing the discipline of ergonomics and human factors is proposed. The method is based upon the journal list, impact factors and citations provided by the Institute of Scientific Information (ISI), and the journal list published in the Ergonomics Abstracts. Three groups of journals were distinguished. The 'ergonomics journals' focus exclusively on ergonomics or human factors. The 'related journals' focus on other disciplines than ergonomics or human factors, but regularly publish ergonomics/human factors papers. The 'basic journals' focus on other technical, medical or social sciences than ergonomics, but are important for the development of ergonomics/human factors. Journal quality was rated using a maximum of four categories: top quality (A-level), high quality (B-level), good quality (C-level)) and professional (P-level). The above methods were applied to develop journal ratings for the year 2003. A total of 24 'ergonomics journals', 58 'related journals' and 142 'basic journals' were classified. 


\section{Introduction}

Articles published in the archival, peer-review journals are considered one of the most important measures of scientific achievements, both in terms of quality and productivity. An evidence of the published work is often used as one of primary criteria for evaluation of one's contribution to the discipline and related recognition of such by the scientific community.

The Institute for Scientific Information (ISI) has selected about 8000 journals that are being considered as high quality scientific journals (ISI 2003). The ISI tracks the number of citations to the articles that have been published in a journal. One of the most popular measures of the journal's quality is the ISI 'impact factor'. The impact factor for a given year is defined as the ratio of the number of citations to the number of articles published in the journal in the two years after the publication date (ISI, 2003). Typically, the ISI- classified journals with the high impact factors in comparison to other journals are considered as the top journals in a given discipline.

In order to support scientists and professionals in selecting journals for their articles, and to stimulate improving the quality of journals in a given field, several disciplines have published rating lists of journals that represent the discipline. For example, in the field of economics and business administration the WU-rating of the Vienna University of Economics and Business Administration (Meier 2002) rates some 2300 journals. In this rating system 5 levels of journals are distinguished. The higher level journals have high scientific reputation, international distribution and readership, broad coverage of the discipline, blind referee procedures and high impact factors.

In the past 50 years, ergonomics and human factors (hereafter called ergonomics) has developed as a separate scientific discipline with its own scientific societies, meetings and publications. Articles in this field are published in journals that focus exclusively on the entire field of ergonomics or its sub-disciplines 
('ergonomics journals'), or in journals that basically focus on other, but related disciplines ('related journals'). Ergonomics journals help to disseminate ergonomics knowledge within the ergonomics community, whereas related journals help to disseminate ergonomics knowledge in other disciplines. Another group of journals focus on a diversity of technical, medical and social sciences. These 'basic journals' normally do not publish ergonomics articles, but the knowledge published in such journals is important to the development and enhancement of the discipline of ergonomics.

In the recent past, several lists of journals in the field of ergonomics have been published. For example, the database of Ergonomics Abstracts contains indexes and abstracts of articles from more than 300 journals, relevant for the field of ergonomics (Ergonomics Abstracts 2003). On the website Ergoweb, some 40 journals are listed (Ergoweb 2003). Furthermore, national ergonomics societies and university groups have published their own journal lists. However, there is no consensus between the existing lists as to the ranking of the available journals. No generally accepted list of journals that represent the ergonomics discipline is available, nor a universally accepted system for rating the quality of these journals exists.

This paper is a first attempt to provide a systematic assessment for rating of journals in the field of ergonomics. The proposed system includes the selection of relevant journals, and the rating of these journals. The system is consequently used to develop the Ergonomics Journal Rating 2003. 


\section{Methods}

\subsection{General}

Definitions

The International Ergonomics Association, representing some 19,000 ergonomics researchers and practitioners world wide, describes ergonomics (human factors) as "the scientific discipline concerned with the understanding of interactions among humans and other elements of a system, and the profession that applies theory, principles, data and methods to design in order to optimise human well-being and overall system performance".

In this paper the term ergonomics includes the term 'human factors', as well as its equivalents in other languages. The term 'journal' refers to a scientific or professional periodical with ISSN-number such as a journal, a magazine or a newsletter.

The impact factor of a journal is defined according to ISI as the number of current citations a journal receives to articles published in the two previous years, divided by the number of articles published in the journal during these years. For example, the 2001 impact factor of a journal equals the number of citations in 2001 to articles published in the journal in 1999 and 2000, divided by the number of articles published in the journal in 1999 and 2000.

\section{System criteria}

The following design criteria were used for developing the system for selecting and rating journals in the field of ergonomics: 1) knowledge relevance (representation), 2) simple categorisation scheme, 3) objectivity, and 4) broad acceptability. Knowledge relevance means that the coverage of the considered journals reflect the discipline of ergonomics according to the above definition of 
ergonomics. Simple categorisation scheme means that the system has a limited number of levels under which the journals are categorised. Objectivity refers to a system that can be applied by different researchers with the same (or similar) results. Finally, a broadly accepted system is a system that uses selection and rating criteria that are also used in rating systems for other disciplines.

\subsection{Journal selection}

Selection criteria

In the scientific disciplines other than ergonomics, several methods have been used for the selection of core journals. Core journals of a discipline can be defined as the list of journals from the respective ISI-category. The category 'ergonomics' of the ISI Social Science Citation Index (SSCI) contains 12 journals. Because only a small number of journals is included, this approach appears to be too limited and restrictive. Another approach for selecting the core journals is to evaluate the journal utilisation habits of visitors of an academic library. However, it seems that the frequency of using journals differ considerably between different user groups (Joswick and Stierman (1997).

Morris and McCain (1998) consider journals as the 'core' jounals if they are covered by the science indexing services of the discipline (such as the Ergonomics Abstracts in the field of ergonomics), have relevant language in the articles' titles, abstracts, or keywords, and have sufficient citation visibility to be included in one of the ISI databases. In this paper, the criteria of Morris and McCain were used for developing the current method for selecting journals in the field of ergonomics.

\section{Selection of ergonomics journals}

The 'ergonomics journals' were defined as journals that focus exclusively on the entire field or on sub-disciplines of ergonomics. Journals are considered to be the 'ergonomics journals' if the name 'ergonomics' is part of the journal name, or if in the 
aims, objective or scope of the journal, specific reference is made to the discipline of ergonomics as the major focus. The list of journals from the Ergonomics Abstracts Online (Ergonomics Abstracts 2003) was used here to make the first selection of ergonomics journals. Based on the authors' knowledge, additional candidate ergonomics journals were added. Both scientific journals (ISI-journals and others) and professional journals were included. In order to develop the final list of ergonomics journals, all journals were evaluated using the above definition of ergonomics journals.

\section{Selection of related journals}

The 'related journals' were defined as journals that focus on other disciplines than ergonomics, but regularly publish ergonomics articles. 'Regularly publish' is defined as the publication of at least 5 ergonomics articles in the last 5 years. In order to avoid journals that have published several ergonomics articles at the same time (e.g. a special issue of a journal), the journal must have ergonomics articles during at least 2 years in the 5-year period. In the list of related journals, an 'ergonomics article' is defined as an article that uses at least one of the words 'ergonomics', 'ergonomic', 'ergonomical' 'ergonomically', 'ergonomist', 'ergonomists', or 'human factors' in the title, the abstract or the keywords of the article.

The ISI databases Science Citation Index Expanded (SCI-EXPANDED), Social Science Citation Index (SSCI), and Arts \& Humanities Citation Index (A\&HCl) were used to select related journals as defined above. In order to distinguish between journals that refer to the ergonomics discipline as 'ergonomics', and journals that refer to the discipline as 'human factors', the keyword-strings: "(ergon*) NOT (human factors)", "(human factors) NOT (ergon*)", were used separately. Articles with the word 'ergonovine' were excluded. The list of related journals contains only the ISI-classified journals; professional (trade) journals (or magazines) were not included. 


\section{Selection of basic journals}

The 'basic journals' were defined as journals that focus on other technical, medical or social disciplines than ergonomics. While the basic journals are important for the development of the discipline of ergonomics, they normally do not publish ergonomics articles as defined under 'related journals'. For selecting the basic journals, the list of Ergonomics Abstracts On-Line was used. From this list, the ergonomics journals and the related journals were excluded, as well as non-ISIjournals. The list of basic journals contains only the ISI-classified journals.

\subsection{Journal rating}

\section{Rating criteria}

The selected ergonomics, related and basic journals were rated according to the following criteria (if relevant):

- Scientific or professional,

- ISI- or non-ISI,

- High or low impact factor.

Scientific journals were considered separately from professional journals, because of the differences in scope: scientific journals concentrate on the production of new knowledge and on scientific readership, whereas professional journals concentrate on the application of knowledge, and are meant for professionals and non-scientific readership. Because of the limited number of professional journals (only for ergonomics journals), all such journals were grouped into one level (P-level).

A journal is considered to be a scientific journal if it publishes peer reviewed papers and has a scientific editorial of advisory board. Within the set of scientific journals, the ISI-classified journals are typically considered to be of higher quality level than the non-ISI journals. Non-ISI scientific journals are rated at level C. Within 
the set of ISI-classified journals, the journals with higher impact factors relative to other journals in the same subject area, are considered to have higher quality (level A) than journals with lower impact factor in that area (level B). The proposed rating method for selected journals is shown in Table 1.

\section{INSERT TABLE 1 ABOUT HERE}

\section{Rating of ergonomics journals}

The rating method was applied to ergonomics journals as follows. An ergonomics ISIclassified journal was rated at level A, if at least half of all other ergonomics ISIjournals have lower impact factors. Otherwise, an ergonomics ISI-journal was rated at level B. If a non-ISI-classified journal is a scientific journal, it was rated at the Clevel. All other ergonomics journals were considered professional journals (P-level).

\section{Rating of related journals}

Since the related journals are all ISI-classified journals, these journals were rated only at level A or level B. The related journal was rated at level A, if at least half of the ISI- journals in the same ISI-category have lower impact factors. An ISI-category is a set of ISI journals classified by ISI into the same subject area. One journal can be classified into more than one ISI-category. If a related journal belongs to more than one ISI-category, that journal is rated at A-level, if it is rated at A-level in at least one category, independent of the rating in the other category. If a related journal is not rated at A-level, it is rated at the $B$ level.

\section{Rating of basic journals}

The selected basic journals are all ISI-classified journals; consequently, only levels A and B apply. Since we question the completeness of the present list of basic journals (see Discussion section under 'basic journals 2003'), and since there is a great 
variety of subject areas of basic journals, for simplicity, the basic journals were rated as if all journals were in the same subject area. As a consequence, the rating of these journals into A- or B-level was based upon the absolute value of the impact factor. A basic journal is rated at level $A$ if at least half of all other basic journals have lower impact factors. Otherwise, it is rated at level $\mathrm{B}$.

\subsection{Ergonomics Journal Rating for 2003}

The above journal selection and rating methods were applied to develop the Ergonomics Journal Rating 2003. The databases of the ISI and of Ergonomics Abstract On-Line, and the database with the most recent impact factors published by the ISI Journal Citation Reports (2001), were examined in January 2003. In the presentations of the results, for each rating-level, the journals are sorted alphabetically.

\section{Results}

\subsection{Selection of journals}

Tables 2-4 show that 24 ergonomics journals, 58 related journals and 142 basic journals were selected.

\subsection{Rating of Journals}

Rating of ergonomics journals

Table 2 shows the rating of the ergonomics journals. There are 3 top journals (Alevel), 3 high quality journals (B-level), 8 good quality journals (C-level) and 10 professional journals (P-level). 
Rating of related journals

Table 3 shows the rating of the related journals. There are 28 top journals (A-level) and 30 high quality journals (B-level).

\section{INSERT TABLE 3 ABOUT HERE}

\section{Rating of basic journals}

Table 4 shows the rating of the 142 basic journals with 71 top journals (A-level) and 71 high quality journals (B-level).

\section{INSERT TABLE 4 ABOUT HERE}

\section{Discussion}

\subsection{Journal rating system}

The developed journal rating system is a first attempt for selecting and rating journals that are relevant for the field of ergonomics and human factors. It appears that the proposed system is representative in the sense that journals are included from all subject areas of ergonomics, where ergonomics is broadly defined according to the description of the International Ergonomics Association. In particular, the group of basic journals covers many different areas because of the broad description of ergonomics that is used in the Ergonomics Abstracts.

The proposed system is relatively simple and straightforward. Journals are selected from existing databases (ISI, Ergonomics Abstracts). Three rating levels for the scientific journals and one rating level for the professional journals were distinguished.

The proposed assessment system is objective in the sense that it can be repeatedly applied by others with the same results. However, the subjective element in the system comes from the selection process of journals in the databases of ISI 
and Ergonomics Abstracts. For example, the ISI editorial staff selects journals on the basis of a combination of editorial content, publishing criteria, and citation history. It remains to be seen whether the rating system developed here, can be broadly accepted. The selection and rating of journals relies heavily on the list of ISI-journals and its impact factors.

Although the ISI-databases are generally considered as valuable tools for selecting and rating (scientific) journals, there has also been criticism of such an approach. For example, only a limited number of high quality regional journals and journals in other languages than English, show up in the list. In general, the true impact factor of any given journal not only depends on the quality of the journals and its articles as measured by the ISI impact factor, which is based on the relative number of citations alone. Other important factors that are, unfortunately, not considered by the ISI impact factor measure (Amin and Mabe 2000) include: 1) the type of article: review articles have higher impact factors than other contributions,

2) the subject area of the journal: fundamental subject areas (i.e. human factors) have higher impact factors than specialised and applied subject areas (i.e.human factors in manufacturing), and

3) the size of the journal: journals with many articles per year have smaller yearly fluctuations of their impact factors.

In the proposed journal rating system for ergonomics, only the dependency of the impact factor on variations in subject area is considered (not for the basic journals). Other factors of variation are not addressed. It is difficult to judge whether the selection and rating of journals is valid, since there is no 'golden standard'. Also, no other rating systems are available for ergonomics. Other journal rating systems should be developed in order to allow comparison with the present rating system. For example, other systems could use different methods for selection of core papers (e.g. bibliographic analyses of journals using cross-citations and inter-citations of articles), 
or different methods for rating of journals (e.g. based on opinions of ergonomics experts).

It should be stressed that journal rating systems such as the one developed here are normally based on the 'classical' view of a division between scientific and professional knowledge: scientists produce knowledge and publish their results in scientific journals, while professionals apply this knowledge in their everyday practise. However, in our opinion, the division between knowledge production and knowledge application is less sharp. In the discipline like ergonomics, academic knowledge and practical knowledge are often combined in order to produce applied knowledge.

\subsection{Ergonomics Journal Rating 2003}

Ergonomics journals 2003

The list of ergonomics A- and B-rated journals is rather small. One reason is that ergonomics journals are strictly defined as journals that primarily focus on ergonomics, as indicted by the name of the journals or by the description of the aims, the objective or the scope of the journal. A valid question would be whether or not to include in the list of ergonomics journals those journals that come from the subfield of human-computer interaction, for example the International Journal of HumanComputer Interaction or the International Journal of Human-Computer Studies. In the last decades the field of human-computer-interaction has developed towards a more independent subject area, but it can be classified as one of the broadly defined subfields of ergonomics. Since such journals refer to ergonomics as only one of the areas of interest (which may help to emphasise the autonomy of the field), these journals are not classified as 'ergonomics journals' according to the definition we have used in this paper. These journals do show up in the list of 'related journals' since they regularly publish ergonomics articles as defined here. As a contrast, the International Journal of Cognitive Ergonomics (even though its publication was 
recently discontinued) refers to ergonomics as the major goal of the journal, both in the journal title and in the scope, and was therefore included in our list.

We believed that the presented list of ergonomics A- and B-rated journals is fairly complete. It is possible that some C- or P-journals, in particular in languages other than English, are missing. With respect to the rating of the 'ergonomics journals, it can be observed that the three A-level journals have a long and good reputation within ergonomics. These journals count for $18 \%$ of the total number of abstracts in the database Ergonomics Abstracts, whereas they represent only $3 \%$ of the total number of journals with more than 10 abstracts (Luczak et al, 1999). From our analysis it turns out that the six A- and B-ergonomics journals have published considerably more ergonomics papers (average 71) than the related journals (average10). These A- and B-rated journals also show up in most ergonomics journal lists that we have found.

\section{Related journals 2003}

There are 58 related journals that have published at least 5 articles in the last 5 years. This is $9 \%$ of all 678 ISI classified journals that have published at least one ergonomics article in the last 5 years. 27 of the 58 related journals have published 10 articles or more.

The definition of an 'ergonomics article' as an article that uses at least one of the words 'ergon*', or 'human factors' in the title, the abstract or the keywords of the article, has its limitations. For example, in one of the ergonomics journals (Human Factors) these keywords are used in only 14 articles (10 times 'ergon*' and 4 times 'human factors'), although it can be assumed that all articles in this ergonomics journal are relevant. This phenomenon might occur in the non-ergonomics journals as well. On the other hand, if a non-ergonomics journal uses ergonomics keywords, one can expect that the article is relevant to ergonomics. Exceptions are articles that use the words 'human factors' in a general way, not referring to the discipline (e.g. 
"human factors causes of climate changes"). However, journals that publish such articles do not reach the threshold of 5 articles in 5 years. Taking these aspects into account, we estimate that the number of related journals might be an underestimation of the total number of relevant related journals.

Table 5 shows the list of 85 ISI-categories in which the 58 'related journals' were classified (one journal can be classified into more than one category). It turns out that ergonomics articles have been published within a variety of disciplines (and ISI journal categories). Eighteen categories (34 journals) are within the field of medicine, human health, and biology, and particularly in the category 'public, environmental \& occupational health' (12 journals). Twelve categories (21 journals) are within the field of engineering and technology, in particular in the category 'industrial engineering' (6 journals), while 7 categories (17 journals) are within the field of computers and information, in particular in the category 'cybernetics' (6 journals).

\section{INSERT TABLE 5 ABOUT HERE}

In the selected 'related journals', the keywords 'ergon*' showed up in twice as many articles than the keywords 'human factors'. Some typical 'ergonomics'-related journals and 'human factors' related journals are shown in Table 6. It appears that ergonomics is used more in the area of occupational health and in applications in medicine, whereas human factors is used more in the 'related journals' in the areas of computer science and engineering, as well as applications in aviation and transport.

With respect to journal ratings, the impact factor of a journal is related to the impact factors of other journals in the same subject area. Consequently, some of the journals with higher impact factors can be rated lower than journals with lower impact factors. For example, the Journal of Electromyography and Kinesiology, that belongs 
to the ISI-categories: Neurosciences and Physiology, has an impact factor of 1.145 and is rated at B-level, whereas the journal Computers \& Industrial Engineering, that belongs to the ISI-categories Interdisciplinary Applications in Computer Science, and Industrial Engineering, has an impact factor of 0.391, but is rated at A-level.

\section{INSERT TABLE 6 ABOUT HERE}

\section{Basic journals 2003}

The selection of 'basic journals' (journals that are important for the development of the discipline of ergonomics) is based on the journal list of Ergonomics Abstracts. This database contains abstracts of 331 journals, including 179 ISI-classified journals. The publisher claims that the database is "spanning the whole wide world of ergonomics and human factors". One would expect that at least the related journals, that publish ergonomics articles regularly, are included in the list. We have found that 10 'related journals' rated at A-level and 18 'related journals' rated at B-level, including several journals that have published more than 10 ergonomics articles, were not part of the journal list of Ergonomics Abstracts. If the journal list contained in the Ergonomics Abstracts is not complete, it could not be the only source for selecting 'basic journals'. Additional approaches, such as selection by experts or analysis based on the bibliographic studies should also be used.

With respect to the rating of the 'basic journals', it should be observed that the classification of a basic journal into level A or level B is based on the ISI impact factor without correction for the subject area. So, the list of 'basic journals' seems less complete and less thoroughly rated than the lists of 'ergonomics journals' and 'related journals'. 


\section{Conclusions}

The proposed journal rating system is a first attempt to select and assess the relevant journals in the field of ergonomics / human factors, and can be the first step towards a generally acceptable rating system. While more analysis is still needed before a consensus on this issue can be reached within the ergonomics community, the proposed evaluation framework allows a longitudinal insight into the current state of development of journals in the ergonomics and human factors discipline.

\section{Acknowledgements}

The authors would like to thank Gert Goris, Deputy Librarian and Head of Documentary Information of the Library of the Erasmus University Rotterdam, for his comments on the manuscript of the paper. 


\section{References}

AMIN, M. and MABE, M. 2000. Impact factors: use and abuse, Perspectives in Publishing, 1, 1-6.

ERGONOMICS ABSTRACTS 2003, http://www.tandf.co.uk/ergoabs/ergo journals.html ERGOWEB 2003, http://www.ergoweb.com/resources/reference/journals.cfm IEA 2003, International Ergonomics Association, http://www.iea.cc ISI 2003, Institute of Scientific Information, http://www.isinet.com/isi/journals/ JOSWICK, K.E. and STIERMAN. J.K. (1997). The core list mirage: a comparison of the journals frequently consulted by faculty and students, College and Research Libraries, 58, 48-55.

LUCZAK H., SCHLICK, C. and SPRINGER, J. (1999), A guide to Scientific Sources of Ergonomics Knowledge (pp 27-50). In: The Occupational Ergonomics Handbook, (Ed. Karwowski W and Marras WS) CRC Press: Boca Raton, 1999.

MEIER, G. 2002, Das Zeitschriftenrating der WU-Wien im internationalen Vergleich. http://www.wu-wien.ac.at/research/rating vergleich.pdf MORRIS, T. A. and McGAIN, K.W. 1998. The structure of Medical Informatics Journal Literature, Journal of the American Medical Informatics Association 5 (5). 448-466. 


\begin{tabular}{|c|l|}
\hline Journal Rating & \multicolumn{1}{|c|}{ Description } \\
\hline A & $\begin{array}{l}\text { ISI journal with relatively high impact } \\
\text { factor }\end{array}$ \\
\hline B & $\begin{array}{l}\text { ISI journal with relatively low impact } \\
\text { factor }\end{array}$ \\
\hline C & Non-ISI, refereed, scientific journal \\
\hline P & $\begin{array}{l}\text { Journal that is primarily meant for } \\
\text { professionals and non-scientific } \\
\text { readership. }\end{array}$ \\
\hline
\end{tabular}

Table 1. Method for rating of journals. 


\begin{tabular}{|c|ll|}
\hline Rating & \multicolumn{1}{|c|}{ Ergonomics journals } \\
\hline A & 1. & Applied Ergonomics (0.672) \\
& 2. & Ergonomics (0.556) \\
& 3. & Human Factors (0.723) \\
\hline B & 1. & International Journal of Industrial Ergonomics (0.354) \\
& 2. & Journal of Human Factors and Ergonomics in Manufacturing (0.188) \\
\hline C. & Le Travail Humain (0.355) \\
\hline & 1. & International Journal of Cognitive Ergonomics \\
& 2. & International Journal of Occupational Safety and Ergonomics \\
& 3. & Japanese Journal of Ergonomics \\
& 4. & Occupational Ergonomics \\
& 5. & Theoretical Issues in Ergonomics Science \\
& 6. & Tijdschrift voor Ergonomie \\
& 7. & Zeitschrift für Arbeitswissenschaft \\
& 8. & Zentralblatt für Arbeitsmedizin, Arbeitsschutz und Ergonomie \\
\hline P & 1. & Ergonomia (Italy) \\
& 2. & Ergonomia (Poland) \\
& 3. & Ergonomics (Australia) \\
& 4. & Ergonomics in Design \\
& 5. & Ergonomics International \\
& 6. & Ergonomics (New Zealand) \\
& 7. & Ergonomics (South Africa) \\
& 8. & Ergonomist \\
& 9. & Human Factors and Ergonomics Society Bulletin \\
& 10. Workplace Ergonomics \\
\hline
\end{tabular}

Table 2. Ergonomics Rating List 2003: Ergonomics journals (impact factor, if available, between brackets). 


\begin{tabular}{|c|c|}
\hline Rating & Related journals \\
\hline$A$ & $\begin{array}{l}\text { 1. ACM Computing Surveys }(0.641,7) \\
\text { 2. ACM Transactions on Information Systems }(2.036,10) \\
\text { 3. American Journal of Industrial Medicine }(1.305,31) \\
\text { 4. Annals of Occupational Hygiene }(1.222,6) \\
\text { 5. Archives of Physical Medicine and Rehabilitation }(1.371,7) \\
6 . \text { Aviation Space and Environmental Medicine }(0.690,28) \\
\text { 7. Behaviour and Information Technology }(0.603,20) \\
\text { 8. Clinical Biomechanics }(1.257,13) \\
\text { 9. Computers \& Education }(0.571,5) \\
\text { 10. Computers \& Industrial Engineering }(0.391,6) \\
\text { 11. European Journal of Applied Physiology }(1.261,7) \\
\text { 12. IEEE Transactions on Systems Man and Cybernetics Part A }(0.582 \text {, } \\
\text { 5) } \\
\text { 13. Intelligent Transport Systems Journal }(0.414,5) \\
\text { 14. Interacting with Computers }(0.561,10) \\
\text { 15. International Journal of Production Research }(0.438,8) \\
\text { 16. Journal of Biomechanics (1.856, } 6) \\
\text { 17. Journal of Laparoendoscopic \& Advanced Surgical Techniques - Part } \\
\text { A (1.069, } 7) \\
\text { 18. Journal of Manipalutive and Physiological Therapeutics }(0.839,6) \\
\text { 19. Journal of Occupational and Environmental Medicine }(1.452,19) \\
\text { 20. Journal of Occupational Rehabilitation }(0.595,15) \\
\text { 21. Journal of the American Medical Informatics Association }(0.794,7) \\
\text { 22. Occupational and Environmental Medicine }(1.973,10) \\
\text { 23. Presence-Teleoperators and Virtual Environments }(1.544,7) \\
\text { 24. Reliability Engineering \& Systems Safety }(0.545,10) \\
\text { 25. Safety Science }(0.609,13) \\
\text { 26. Scandinavian Journal of Work and Environmental Health }(1.590,19) \\
\text { 27. Spine (1.853, 15) } \\
\text { 28. Surgical Endoscopy (2.374, } 30)\end{array}$ \\
\hline$B$ & $\begin{array}{l}\text { 1. Aerospace Engineering }(0.045,5) \\
\text { 2. AlHAJ }(0.241,6) \\
\text { 3. American Industrial Hygiene Association Journal }(0.685,10) \\
\text { 4. Applied Psychophysiology and Biofeedback }(0.514,5) \\
\text { 5. ATW-Internationale Zeitschrift für Kernenergie }(0.020,5) \\
\text { 6. Collegium Antropologicum }(0.414,7) \\
\text { 7. Contempory psychology }(-, 5) \\
\text { 8. Cyberpsychology \& Behavior }(-, 5) \\
\text { 9. Diplays }(0.443,14) \\
\text { 10. IIE Solutions }(-, 27) \\
\text { 11. Industrial Health }(0.741,10) \\
\text { 12. International Archives of Occupational and Environmental Health } \\
\text { (0.924, } 15) \\
\text { 13. International Journal of Aviation Psychology }(0.609,7) \\
\text { 14. International Journal of Human-Computer-Interaction }(0.359,12) \\
\text { 15. International Journal of Human-Computer Studies }(0.471,15) \\
\text { 16. International Journal of Vehicle Design }(0.190,7) \\
\text { 17. Journal of Clinical and Monitoring and Computing }(-,, 10) \\
\text { 18. Journal of Construction Engineering and Management ASCE }(0.254, \\
\text { 5) } \\
\text { 19. Journal of Electromyography and Kinesiology }(1.145,7) \\
\text { 20. Journal of Navigation }(0.102,16) \\
\text { 21. Journal of Occupational Health }(0.935,6) \\
\text { 22. Lecture Notes in Computer Science }(0.415,13) \\
\text { 23. Minimally Invasive Therapy \& Allied Technologies }(0.393,12) \\
\text { 24. Occupational Medicine - Oxford }(0.533,12) \\
\text { 25. Orthopade }(0.434,5) \\
\text { 26. Perceptual and Motor Skills }(0.271,6) \\
\text { 27. Process safety progress }(0.247,5) \\
\text { 28. Revista de Saude Publica }(0.134,5) \\
\text { 29. Transport Research Record }(0.038,10) \\
\text { 30. Workforce }(-, 6)\end{array}$ \\
\hline
\end{tabular}


Table 3. Ergonomics Rating List 2003: Related journals (between brackets are the impact factor, if available, and the number of ergonomics articles in last 5 years, respectively). 


\begin{tabular}{|c|c|}
\hline Rating & Basic Journals \\
\hline$A$ & 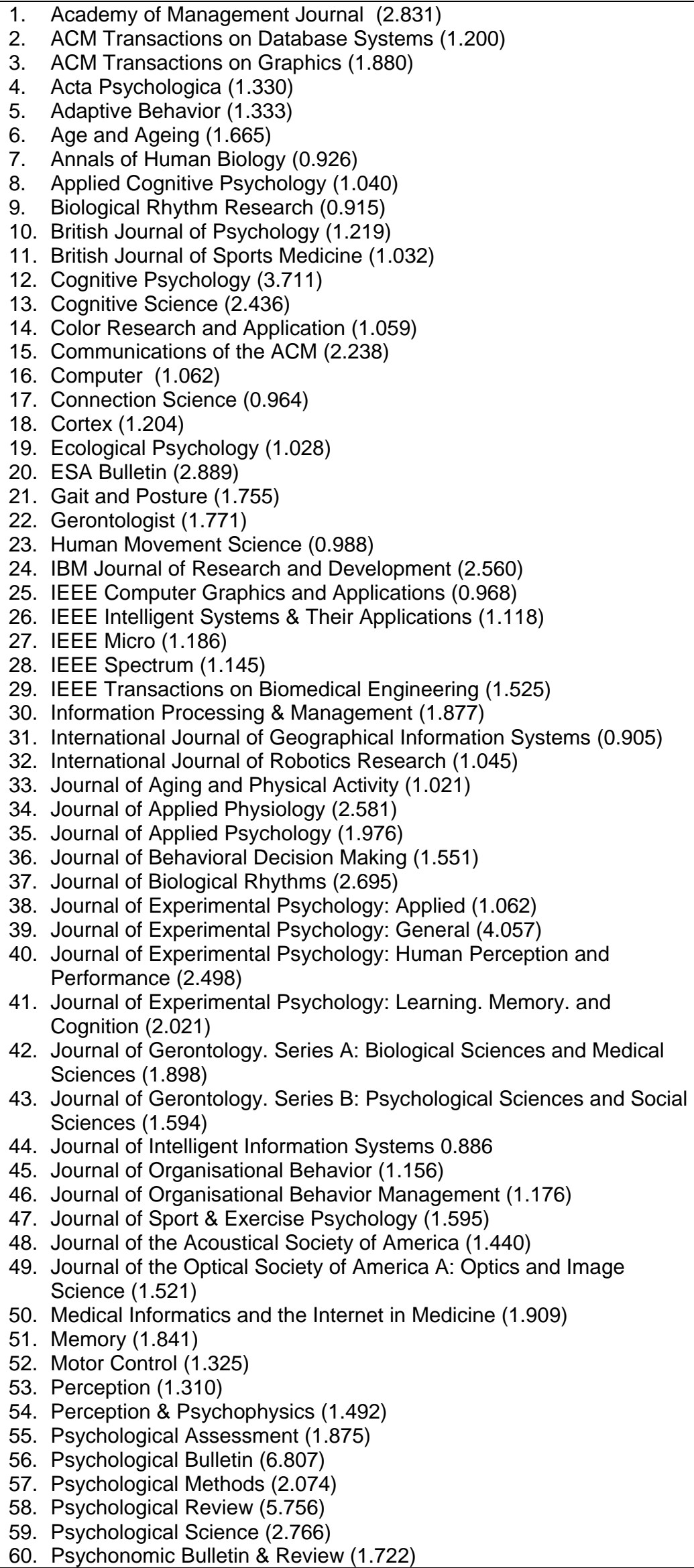 \\
\hline
\end{tabular}




\begin{tabular}{|l|l|}
\hline & 61. Psychophysiology (3.035) \\
62. Quarterly Journal of Experimental Psychology. Section A: Human \\
Experimental Psychology (2.416) \\
63. Research Quarterly for Exercise and Sport (2.342) \\
64. Risk Analysis (1.791) \\
65. Scandinavian Journal of Rehabilitation Medicine (1.101) \\
66. Sports Medicine (2.189) \\
67. Transportation Research Part B: Methodological (1.254) \\
68. Trends in Cognitive Sciences (11.606) \\
69. User Modeling and User-Adapted Interaction (1.941) \\
70. Vision Research (2.013) \\
71. Work and Stress (1.585) \\
\hline
\end{tabular}




\begin{tabular}{|c|c|}
\hline$B$ & 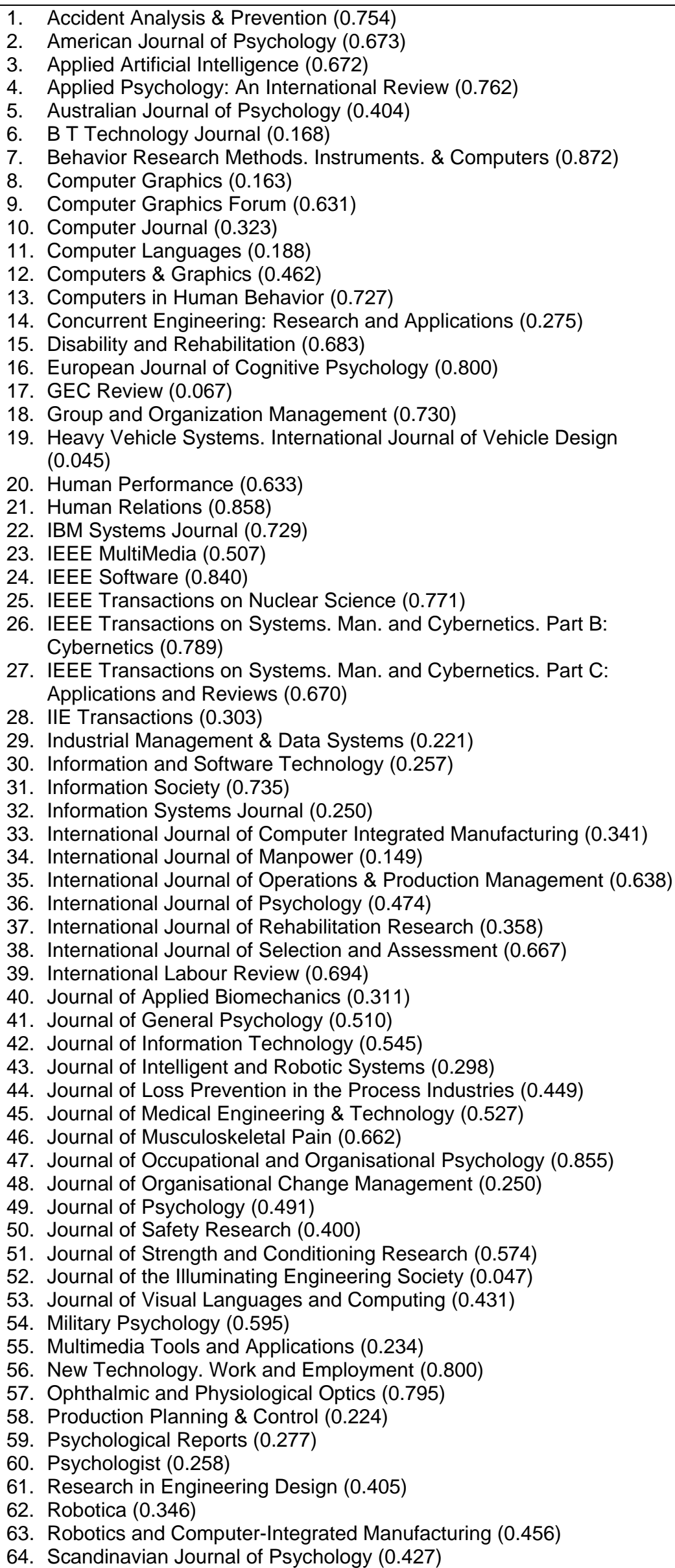 \\
\hline
\end{tabular}




\begin{tabular}{|l|l|}
\hline & 65. South African Journal of Psychology $(0.245)$ \\
& 66. Speech Communication $(0.446)$ \\
67. Strength and Conditioning $(0.302)$ \\
68. Transport Reviews $(0.182)$ \\
69. Transportation Research Part A: Policy and Practice $(0.531)$ \\
70. Transportation Research Part C: Emerging Technologies $(0.171)$ \\
71. Transportation Research Part D: Transport and Environment $(0.778)$ \\
\hline
\end{tabular}

Table 4. Ergonomics Rating List 2003: Basic journals (impact factors between brackets). 
Medicine, Health and Biology

applied psychology, biophysics, clinical neurology, clinical psychology, experimental psychology, general \& intermediate medicine, health care science and services, integrative \& complementary medicine, multidisciplinary psychology, neurosciences, orthopaedics, physiology, public environmental \& occupational health, rehabilitation, sport sciences, surgery, toxicology.

\section{Engineering and Technology}

aerospace engineering, biomedical engineering, chemical engineering, civil engineering, construction \& building technology, electrical and electronical engineering, industrial engineering, manufacturing engineering, marine engineering, mechanical engineering, nuclear science \& technology, transportations science and technology.

\section{Computer and Information}

cybernetics in computer science, hardware \& architecture in computer science, information science \& library science, information systems in computer science, interdisciplinary applications in computer science, software engineering in computer science, theory and methods in computer science.

\section{Other}

anthropology, education and educational research, environmental sciences, oceanography, operations research and management science, social issues.

Tabel 5 Topics (ISI-categories) covered by related journals. 


\begin{tabular}{|c|c|}
\hline 'Ergonomics' related journals & 'Human factors' related journals \\
\hline 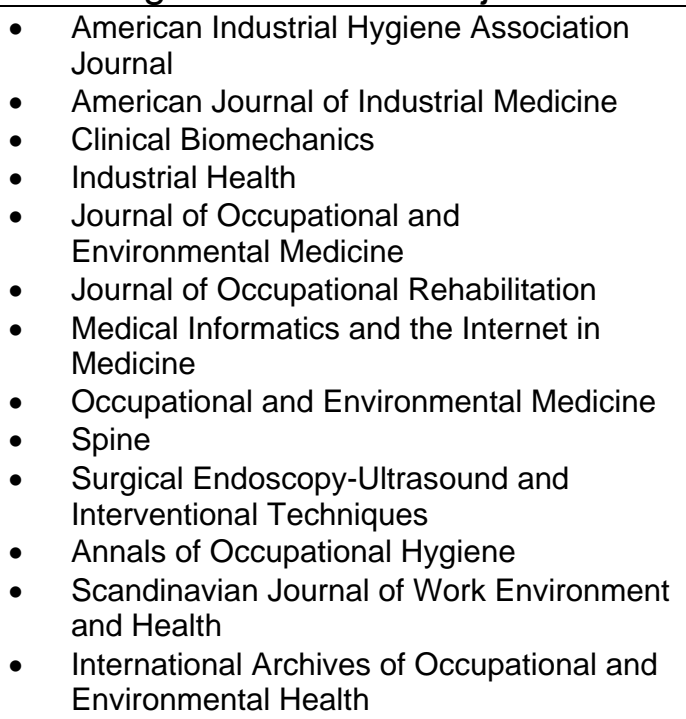 & $\begin{array}{ll}\text { - } & \text { ACM Transactions on Information Systems } \\
\text { - } & \text { Intelligent Transport Systems Journal } \\
\text { - } & \text { Journal of the American Medical Informatics } \\
& \text { Association } \\
\text { - } & \text { Journal of Navigation } \\
\text { - } & \text { International Journal of Aviation Psychology } \\
\text { - } & \text { Reliability Engineering \& Systems Safety }\end{array}$ \\
\hline
\end{tabular}

Tabel 6 Some typical 'ergonomics' related journals and 'human factors' related journals. 


\section{Publications in the Report Series Research* in Management}

ERIM Research Program: "Business Processes, Logistics and Information Systems"

\section{3}

Project Selection Directed By Intellectual Capital Scorecards

Hennie Daniels and Bram de Jonge

ERS-2003-001-LIS

http://hdl.handle.net/1765/265

Combining expert knowledge and databases for risk management

Hennie Daniels and Han van Dissel

ERS-2003-002-LIS

http://hdl.handle.net/1765/266

Recursive Approximation of the High Dimensional max Function

Ş. II. Birbil, S.-C. Fang, J.B.G. Frenk and S. Zhang

ERS-2003-003-LIS

http://hdl.handle.net/1765/267

Auctioning Bulk Mobile Messages

S.Meij, L-F.Pau, E.van Heck

ERS-2003-006-LIS

http://hdl.handle.net/1765/274

Induction of Ordinal Decision Trees: An MCDA Approach

Jan C. Bioch, Viara Popova

ERS-2003-008-LIS

http://hdl.handle.net/1765/271

A New Dantzig-Wolfe Reformulation And Branch-And-Price Algorithm For The Capacitated Lot Sizing Problem With Set Up Times

Zeger Degraeve, Raf Jans

ERS-2003-010-LIS

http://hdl.handle.net/1765/275

Reverse Logistics - a review of case studies

Marisa P. de Brito, Rommert Dekker, Simme D.P. Flapper

ERS-2003-012-LIS

http://hdl.handle.net/1765/277

Product Return Handling: decision-making and quantitative support

Marisa P. de Brito, M. (René) B. M. de Koster

ERS-2003-013-LIS

http://hdl.handle.net/1765/278

* A complete overview of the ERIM Report Series Research in Management: $\underline{\text { http://www.erim.eur.nl }}$

ERIM Research Programs:

LIS Business Processes, Logistics and Information Systems

ORG Organizing for Performance

MKT Marketing

F\&A Finance and Accounting

STR Strategy and Entrepreneurship 
Managing Product Returns: The Role of Forecasting

Beril Toktay, Erwin A. van der Laan, Marisa P. de Brito

ERS-2003-023-LIS

http://hdl.handle.net/1765/316

Improved Lower Bounds For The Capacitated Lot Sizing Problem With Set Up Times

Zeger Degraeve, Raf Jans

ERS-2003-026-LIS

http://hdl.handle.net/1765/326

In Chains? Automotive Suppliers and Their Product Development Activities

Fredrik von Corswant, Finn Wynstra, Martin Wetzels

ERS-2003-027-LIS

http://hdl.handle.net/1765/363

Mathematical models for planning support

Leo G. Kroon, Rob A. Zuidwijk

ERS-2003-032-LIS

http://hdl.handle.net/1765/332

How and why communications industry suppliers get "squeezed out" now, and the next phase

L-F Pau

ERS-2003-033-LIS

http://hdl.handle.net/1765/317

Financial Markets Analysis by Probabilistic Fuzzy Modelling

Jan van den Berg, Uzay Kaymak, Willem-Max van den Bergh

ERS-2003-036-LIS

http://hdl.handle.net/1765/323

WLAN Hot Spot services for the automotive and oil industries :a business analysis or : "Refuel the car with petrol and information, both ways at the gas station "

L-F Pau, M.H.P.Oremus

ERS-2003-039-LIS

http://hdl.handle.net/1765/318

A Lotting Method for Electronic Reverse Auctions

U. Kaymak, J.P. Verkade and H.A.B. te Braake

ERS-2003-042-LIS

http://hdl.handle.net/1765/337

Supply Chain Optimisation in Animal Husbandry J.M. Bloemhof, C.M. Smeets, J.A.E.E. van Nunen

ERS-2003-043-LIS

http://hdl.handle.net/1765/353

A Framework for Reverse Logistics

Marisa P. de Brito and Rommert Dekker

ERS-2003-045-LIS

http://hdl.handle.net/1765/354

An assessment system for rating scientific journals in the field of ergonomics and human factors Jan Dul and Waldemar Karwowski

ERS-2003-048-LIS 